\title{
FOREST FIRE RISK ZONING FOR THE VILA VELHA STATE PARK AND ITS SURROUNDINGS (PONTA GROSSA, PARANÁ)
}

\author{
Bruna Kovalsyki ${ }^{*}$, Alexandre França Tetto ${ }^{2}$, Antonio Carlos Batista ${ }^{2}$, Nilton José Sousa ${ }^{2}$, Marta Regina Barrotto \\ do $\mathrm{Carmo}^{3}$, Ronaldo Viana Soares ${ }^{4}$

\begin{abstract}
1*Federal University of Paraná, Graduate Program in Forest Engineering, Curitiba, Paraná, Brazil - kovalsyki.b@ gmail.com 2Federal University of Paraná, Department of Forest Sciences, Curitiba, Paraná, Brazil, tetto@ufpr.br; batistaufpr@ufpr.br; nilton.ufpr@gmail.com

3State University of Ponta Grossa, Department of General Biology, Ponta Grossa, Paraná, Brazil - mrcarmo@uepg.br 4Federal University of Paraná, Department of Forest Sciences, Curitiba, Paraná, Brazil, rvsoares@ufpr.br
\end{abstract} \\ Received for publication: 11/04/2019 -Accepted for publication: 10/08/2019
}

\begin{abstract}
Resumo
Zoneamento de risco de incêndios florestais para o Parque Estadual de Vila Velha e seu entorno (Ponta Grossa, Paraná). O Zoneamento de Risco de Incêndios Florestais (ZRIF) é uma ferramenta fundamental para o planejamento e tomada de decisões quanto à prevenção e ao combate de incêndios, assim como ao uso do fogo, uma vez que permite a visualização espacial de áreas com maior e menor probabilidade de ocorrências de incêndios. O presente estudo teve por objetivo elaborar um ZRIF para o Parque Estadual de Vila Velha e seu entorno (Ponta Grossa, Paraná), para o período de alta incidência de incêndios florestais (de abril a setembro) e para o período de baixa incidência (de outubro a março). Identificaram-se as seguintes variáveis de risco e perigo: presença humana, zonas de uso, características topográficas, cobertura e uso do solo e condições meteorológicas. Os mapas para cada variável foram elaborados a partir da atribuição de coeficientes (de 0 a 5), que traduzem o grau de risco ou perigo de incêndios. A integração destes mapas, por meio de um modelo de ponderação, resultou no ZRIF do parque. As classes de risco muito alto e extremo representaram, aproximadamente, $38 \%$ da área para ambos os períodos. Os ZRIFs representaram espacialmente os níveis de risco de incêndios da área, a partir dos quais pode-se identificar a porção leste do parque e as zonas de influência da rodovia como prioritárias para ações preventivas durante os dois períodos.

Palavras-chave: Proteção florestal; perigo de incêndio; áreas protegidas; prevenção e combate aos incêndios; mapeamento.
\end{abstract}

\begin{abstract}
Forest fire hazard and risk mapping is an essential tool for planning and decision making regarding the prevention and suppression of forest fires,as well as fire management in general, as it allows the spatial visualization of areas with higher and lower ignition probability. This study aimed to develop a forest fire risk zoning map for the Vila Velha State Park and its surroundings (Ponta Grossa, Paraná State, Brazil), for the period of higher incidence of forest fires (from April to September) and for the period of lower incidence (from October to March). The following risk and hazard variables were identified: human presence, usage zones, topographical features, soil coverage and land use and meteorological conditions. Coefficients (0 to 5) reflecting the fire risk or hazard degree were allocated to each variable in order to construct the maps. The integration of these maps, through a weighting model, resulted in the final risk mapping. The very high and extreme risk classes represented about $38 \%$ of the area for both periods. The forest fire risk mapping spatially represented the levels of fire risk in the area, allowing the managers to identify the priority sectors for preventive actions in both fire seasons.

Keyworks: Forest protection, fire hazard, protected areas, prevention and suppression.
\end{abstract}

\section{INTRODUCTION}

The occurrence of fire influences the patterns and processes of the global ecosystem, including the distribution and vegetation structure, carbon cycle and microclimate (BOWMAN et al., 2011). According to Soares et al. (2017), every ecosystem has potentially a fire regime, defined as a set of recurring conditions of the fire that characterizes it. However, these regimes are changed (SOARES NETO et al., 2016) due to the influence anthropic through modifications in the structure, continuity, type and quantity of the combustible material, as well as as in the frequency of fires in different seasons, under different weather conditions (BOWMAN et al., 2011), resulting in negative effects (SOARES NETO et al., 2016). In this way, changes in fire have been considered a threat to the conservation of biodiversity and ecological processes (MYERS, 2006).

The term forest fire is generally used to refer to fire that spreads freely and consumes different types of vegetation, including scrub, fields and grasslands (SOARES et al., 2017). Caúla et al. (2015) emphasized the need to improve the existing control and detection systems for these events in Brazil. However, Bovio et al. (2017) pointed out that forest fire management does not end with prevention and extinction, but it also concerns the prediction of danger before the fire and post-fire reconstitution.

FLORESTA, Curitiba, PR, v. 50, n. 4, p. 1818 - 1826, out/dez 2020.

Kovalsyki, B. et.al.

ISSN eletrônico 1982-4688

DOI: $10.5380 /$ rf.v50 i4. 65974 
One of the fundamental instruments for this management is the Forest Fire Risk Zoning (ZRIF), which allows spatial visualization of areas according to its potential for occurrence and propagation of the fire (KOPROSKI et al., 2011). In this way, ZRIF offers support for decision making and adaptation of prevention and combat resources and equipment (SOARES NETO et al., 2016), how to intensify surveillance in areas of greater risk, restrict access to these places, build preventive fire breaks, reorganize fire management and assist in the construction of access roads to places of risk (FERRAZ; VETTORAZZI, 1998). Even so, Koproski et al. (2011) state that few Conservation Units (UCs) in Brazil have prevention and control of forest fires with established risk zoning, or even a record of occurrences of these events.

The grassy-woody steppe, or region of Campos Gerais do Paraná, is considered a fire-dependent ecosystem (MYERS, 2006). Predominantly composed of grassland vegetation, interspersed with forests galleries and vegetation islands of mixed ombrophilous forest, it presents a high risk of fire (SEGER et al., 2018). Admittedly a biodiversity hotspot, the region has high biotic potential and exuberant species richness, its main remnants are found mainly in conservation units, since these vegetal formations have been suffering strong anthropic pressure with the expansion of agricultural, livestock and silvicultural activities (DALAZOANA; MORO, 2011).Vila Velha State Park is a fully protected UC, created with the purpose of preserving one of the main remnants of grassy-woody steppe (INSTITUTO AMBIENTAL DO PARANÁ (IAP), 2004).

In addition to preventive planning for forest fires, since 2014 the park management has carried out fire management as a conservation strategy for this ecosystem (IAP, 2018). In this context, the present study aimed to elaborate a Forest Fire Risk Zoning for the Vila Velha State Park (PR) and its surroundings, in order to subsidize the fire management actions to be developed in this conservation unit.

\section{Study area}

This research was carried out in Vila Velha State Park, located in the Paraná second plateau, in the region called Campos Gerais, municipality of Ponta Grossa, state of Paraná, between the coordinates $25^{\circ} 12^{\prime} 34^{\prime}$ 'to 25 $\circ 15^{\prime} 35^{\prime \prime} \mathrm{S}$ and $49^{\circ} 58^{\prime} 04^{\prime \prime}$ to $50^{\circ} 03$ ' $37^{\prime}$ ' $\mathrm{W}$, with altitudes ranging from 800 to $1000 \mathrm{~m}$ (IAP, 2004). To this study an area of influence of $1 \mathrm{~km}$ (buffer) from the unit boundary was considered, since in this area activities that are developed present the potential to start a fire. The total study area was 6,178.8 ha.

According to the Köppen climate classification system, the region is characterized as $\mathrm{Cfb}$ - temperate climate, without defined dry season. It has an average annual rainfall of 1,554 mm, with January being the month with the highest precipitation $(186.5 \mathrm{~mm})$ and August with the lowest precipitation $(78.9 \mathrm{~mm})$. The occurrence of frosts is concentrated in the period from May to August (NITSCHE et al., 2019). The main vegetable typologies are: grassy-woody steppe (23.4\% of the study area), predominant in the park domain, agriculture (18.1\%), located in the area surrounding the unit, and mixed montane rain forest $(16.1 \%)$.

\section{Data gathering}

For the Vila Velha State Park, two forest fire risk zones were made, one for the period of high incidence and another for the period of low incidence of forest fires. These were defined based on information from the municipality of Ponta Grossa (PR), considering monthly values from 2006 to 2014, through a cluster analysis, considering the following variables: number of days with precipitation $\geq 2.4 \mathrm{~mm}$, average precipitation $(\mathrm{mm})$, average relative humidity $(\%)$, average temperature ( $\left.{ }^{\circ} \mathrm{C}\right)$ (PARANÁ METEOROLOGICAL SYSTEM (SIMEPAR), 2015); number of days with fires occurring, number of occurrences of fires (SYSBM-CCB, 2015) and average value of the Monte Alegre Formula (FMA).

The park's fragility in regarding forest fires was quantified and qualified through the analyzes of the following parameters: human presence (infrastructure and areas of use), slope, altimetry, slope orientation , vegetation cover and weather conditions. Thematic maps referring to declivity, altimetry and slope orientation were elaborated based on the Digital Elevation Model (MDE), of sheet 25S51, made available by the TOPODATA project (NATIONAL INSTITUTE FOR SPACE RESEARCH (INPE), 2011), which has a 30 meter resolution. Thematic maps of human presence and vegetation cover were based on information made available by IAP and classification of use by means of RapidEye satellite images (MINISTRY OF THE ENVIRONMENT (MMA), 2013). Thematic maps, referring to meteorological conditions, were made based on the indexes obtained from the Monte Alegre Formula (FMA) adjusted for the region by Kovalsyki (2016).

The ZRIFs were obtained by superimposing thematic maps, according to a model of weighting for Forest Fire Risk (RIF). All spatial analyzes and cartographic production were carried out using a geographic information system with the aid of ArcGIS 10 software.

\section{Fire hazard and risk maps}

To represent the risk according to human presence, maps were prepared based on the infrastructure and in the use zones. For risk maps according to infrastructure, the following factors were considered: highway,

FLORESTA, Curitiba, PR, v. 50, n. 4, p. 1818 - 1826, out/dez 2020.

Kovalsyki, B. et.al.

ISSN eletrônico 1982-4688

DOI: 10.5380/rf.v50 i4. 65974 
railroad, roads, fire breaks and buildings in the park areas. Ferraz and Vettorazzi (1998) considered for means of access, an area of influence proportional to the flow of people and vehicles passing through it. This way, influence radii were stipulated, for which coefficients were attributed. These coefficients reflect the risk level, and are based on the literature, as shown in Table 1, with the domain of roads and fire breaks classified as null risk (coefficient $0)$.

Table 1. Forest fire risk classification according to Vila Velha State Park infrastructure and its surroundings, Paraná State, Brazil

Tabela 1. Classificação de risco de incêndio florestal, segundo a infraestrutura do Parque Estadual de Vila Velha e seu entorno, Paraná, Brasil

\begin{tabular}{|c|c|c|c|c|}
\hline Infraestrutura & $\begin{array}{l}\text { Influence } \\
\text { radius }(\mathbf{m})\end{array}$ & Risk Level & Coefficient & Observations \\
\hline \multirow{3}{*}{ Highway } & 50 & extreme & 5 & \multirow{3}{*}{ Heavy traffic of vehicles and people } \\
\hline & 100 & very high & 4 & \\
\hline & 150 & high & 3 & \\
\hline Railroad & 60 & very high & 4 & - \\
\hline Main roads & 80 & very high & 4 & $\begin{array}{l}\text { Restricted park use paved roads, exclusive to } \\
\text { visitors and employees }\end{array}$ \\
\hline Secondary roads & 50 & very high & 4 & $\begin{array}{l}\text { Restricted park use unpaved roads, exclusive to } \\
\text { visitors and employees }\end{array}$ \\
\hline Buildings & 50 & high & 3 & - \\
\hline Firebreaks & 50 & low & 1 & Exclusive to visitors and employees \\
\hline
\end{tabular}

Source: FERRAZ; VETORAZZI (1998); KOPROSKI et al. (2011), adapted by the authors .

For the forest fire risk map, according to the areas of use and the area surrounding the Vila Velha State Park, values that reflect the level of danger were attributed based on the classification developed by Tetto et al. (2012) (Table 2)

Table 2. Forest fire risk classification according to Vila Velha State Park zones of use and its surroundings, Paraná State, Brazil

Tabela 2. Classificação do risco de incêndio florestal, segundo as zonas de uso do Parque Estadual de Vila Velha e seu entorno, Paraná, Brasil

\begin{tabular}{lcc}
\hline Zones of use & Risk & Coefficient \\
\hline Intensive & extreme & 5 \\
$\begin{array}{l}\text { Extensive } \\
\text { Conflitant }\end{array}$ & very high & 4 \\
\hline $\begin{array}{l}\text { Surrounding } \\
\text { Zone of special use }\end{array}$ & high \\
\hline $\begin{array}{l}\text { Primitive zone } \\
\text { Historic cultural zone } \\
\text { Recuperation zone }\end{array}$ & 3 \\
\hline Temporary use zone & moderate & 2 \\
\hline
\end{tabular}

Source: TETTO et al. (2012), adapted by the authors.

For topographic characteristics, aspects related to the slope of the land were analyzed, altimetry and orientation of the slopes, and the hazard coefficients that were determined according to Batista et al.(2002) (Table $3)$.

Table 3. Forest fire hazard classification according to topographical characteristics of Vila Velha State Park and its surroundings, Paraná State, Brazil

Tabela 3. Classificação do perigo de incêndio florestal, segundo as características topográficas do Parque Estadual de Vila Velha e seu entorno, Paraná, Brasil

\begin{tabular}{cccc}
\hline Topography & Class & Hazard & Coefficient \\
& $\geq 46$ & extreme & 5 \\
& $36-45$ & very high & 4 \\
Slope $(\%)$ & $26-35$ & high & 3 \\
& $16-25$ & moderate & 2 \\
& up to 15 & low & 1 \\
\hline
\end{tabular}

FLORESTA, Curitiba, PR, v. 50, n. 4, p. 1818 - 1826, out/dez 2020

Kovalsyki, B. et.al.

ISSN eletrônico 1982-4688 


\begin{tabular}{cccc} 
& up to 600.00 & extreme & 5 \\
Altimetry $(\mathrm{m})$ & $600.01-900.00$ & very high & 4 \\
& $900.01-1200.00$ & high & 3 \\
& $1200.01-1500.00$ & moderate & 2 \\
& over 1500.00 & low & 1 \\
\hline & $337.51-22.50$ & extreme & 5 \\
Orientation $\left(^{\circ}\right)$ & $247.51-337.50$ & very high & 4 \\
& $22.51-67.50$ & high & 3 \\
\hline
\end{tabular}

Source BATISTA et al. (2002).

Land cover and use was divided into six fire hazard classes: null, low, moderate, high, very high and extreme, with their respective coefficients (TABLE 4).

Table 4. Forest fire hazard classification according to soil coverage and land use of Vila Velha State Park and its surroundings, Paraná State, Brazil

Tabela 4. Classificação do perigo de incêndio florestal, segundo a cobertura e uso de solo do Parque Estadual de Vila Velha e seu entorno, Paraná, Brasil

\begin{tabular}{|c|c|c|}
\hline Soil coverage & Hazard & Coefficient \\
\hline $\begin{array}{l}\text { Steppe } \\
\text { Pinus } \\
\text { Bushes } \\
\end{array}$ & extreme & 5 \\
\hline $\begin{array}{l}\text { Agriculture/pasture } \\
\text { Abandoned Agriculture } \\
\text { forest initial stage } \\
\text { Araucaria densification } \\
\text { Araucaria and eucalyptus } \\
\text { Araucaria and pinus }\end{array}$ & very high & 4 \\
\hline $\begin{array}{l}\text { Hygrophilic steppe } \\
\text { Alluvial mixed rainforest } \\
\text { Montana mixed rainforest } \\
\text { River influence formation } \\
\text { Eucalyptus } \\
\text { Removed plantation } \\
\text { Floodplain }\end{array}$ & high & 3 \\
\hline $\begin{array}{l}\text { Mowed field } \\
\text { Pictograph sites }\end{array}$ & low & 1 \\
\hline $\begin{array}{l}\text { Water } \\
\text { Furnas } \\
\text { Roads } \\
\text { Firebreaks } \\
\text { Buildings }\end{array}$ & null & 0 \\
\hline
\end{tabular}

In this classification, zero hazard was attributed both to the water category and to the infrastructure (roads, buildings and firebreaks), since these act as a physical barrier for the spreading of fire. The class "Extreme" corresponds to areas with combustible material known as dangerous, referring to the thin material which, under natural conditions, proves to be easy and quick to burn.

The meteorological conditions were represented by means of the fire hazard index of the Monte Alegre Formula - FMA (SOARES et al., 2017) adjusted for the region, as this reflects the probability of occurrence, based on atmospheric conditions. FMA was calculated daily with meteorological data provided by SIMEPAR (2015) for the period between 2006 and 2014 and, through the values obtained, the average for two scenarios: a) months that cover the normal fire season; and b) months that cover the least favorable period of incidence. For each class of the FMA, a coefficient referring to the degree of fire hazard, ranging from zero (null) to 4 (very high) was attributed. 


\section{Forest Fire Risk Zoning (ZRIF)}

The forest fire risk zoning for Vila Velha State Park and its surroundings were elaborated through the superposition of the maps made in the previous steps, using the following equation

$\mathrm{ZRIF}=(0,655 * I F+0,0655 * Z U)+[(0,29 * D \%+0,11 * O E+0,1 * A L)+(0,61 * F M A)+(0,8 * C V)]$

where: $\mathrm{IF}=$ infrastructure; $\mathrm{ZU}=$ use zoning; $\mathrm{D} \%=$ slope; $\mathrm{OE}=$ slope orientation; $\mathrm{AL}=$ altimetry; $\mathrm{FMA}=$ degree of fire hazard; $\mathrm{CV}=$ vegetation cover.

The weighting model used, was adapted from Batista et al. (2002), since this was indicated by the same authors for the elaboration of fire risk zoning in the state of Paraná, due to the number of variables used and because it was elaborated using climatic conditions similar to those of the study area. The classification attributed to zoning included six classes: null, low, moderate, high, very high and extreme, established by the quantile method for each of the scenarios. For the purpose of validating the risk assessments of forest fires, we used the burn scars of areas burned between 2015 and 2018, through the visual interpretation of the false color composition of the Landsat images, from the United States Geological Survey (USGS) Earth Explorer database. For sensors ETM + the Red-Green-Blue composition used was: band $5(1550-1750 \mathrm{~nm})$, band $4(760-900 \mathrm{~nm})$ and band $3(630-690$ $\mathrm{nm})$; while for OLI sensor: band $6(1570-1650 \mathrm{~nm})$, band $5(850-880 \mathrm{~nm})$ and band $4(640-670 \mathrm{~nm})$.

\section{RESULTS}

It was observed that the period of high incidence of forest fires in the municipality of Ponta Grossa goes from April to September, while the period of low fire incidence was from October to March.

\section{Thematic maps}

Thematic maps of risk and danger of forest fires for the Vila Velha State Park and its surroundings are represented in Figure 1.

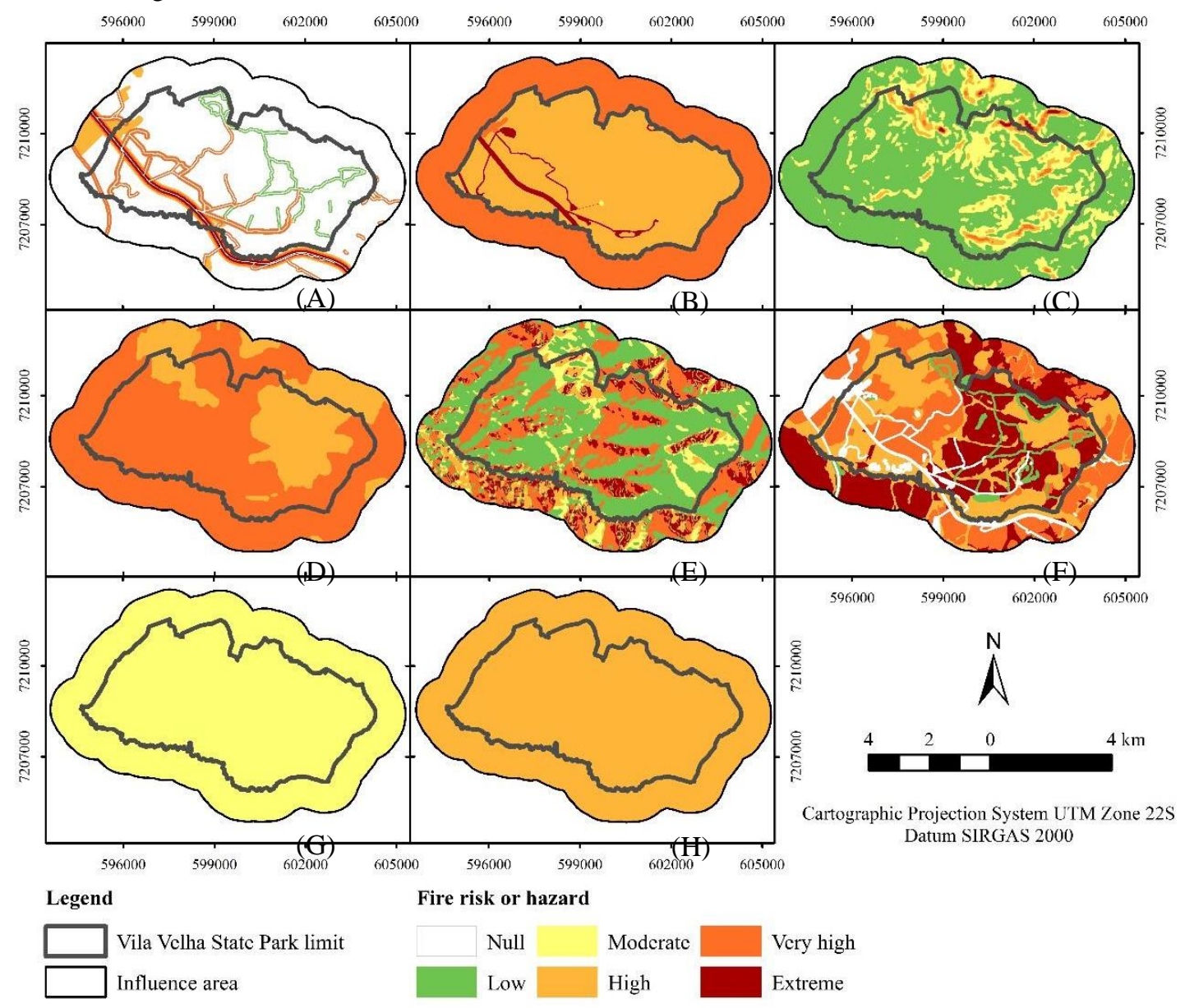

FLORESTA, Curitiba, PR, v. 50, n. 4, p. 1818 - 1826, out/dez 2020

Kovalsyki, B. et.al. 
Figure 1. Maps of risk and hazard, according to (A) infrastructure; (B) usage zones; (C) slope; (D) altimetry; (E) aspect orientation; (F) soil coverage and land use; $(\mathrm{G})$ and $(\mathrm{H})$ meteorological conditions for the Ponta Grossa city.

Figura 1. Mapas temáticos de risco e perigo, segundo (A) infraestrutura; (B) zonas de uso; (C) declividade; (D) altimetria; (E) orientação de encostas; (F) cobertura e uso do solo; $(\mathrm{G})$ e $(\mathrm{H})$ condições meteorológicas para o município de Ponta Grossa.

Note: $(\mathrm{G})$ : meteorological condition for the period of low fire incidence and $(\mathrm{H})$ for the period of high fire incidence.

Table 5 shows the representativeness of each class of danger and risk of forest fires for the overload factors.

Table 5. Representativeness of hazard and risk classes of forest fire by factor of influence

Tabela 5. Representatividade das classes de perigo e risco de incêndios florestais por fator de influência

\begin{tabular}{|c|c|c|c|c|c|c|c|c|c|c|c|c|}
\hline \multirow{3}{*}{ Factor } & \multicolumn{12}{|c|}{ Fire hazard and risk classes } \\
\hline & \multicolumn{2}{|c|}{ Null } & \multicolumn{2}{|c|}{ Low } & \multicolumn{2}{|c|}{ Moderate } & \multicolumn{2}{|c|}{ High } & \multicolumn{2}{|c|}{ Very high } & \multicolumn{2}{|l|}{ Extreme } \\
\hline & $\begin{array}{c}\text { Area } \\
\text { (ha) }\end{array}$ & $\%$ & $\begin{array}{c}\text { Area } \\
\text { (ha) }\end{array}$ & $\%$ & $\begin{array}{c}\text { Area } \\
\text { (ha) }\end{array}$ & $\%$ & $\begin{array}{c}\text { Area } \\
\text { (ha) }\end{array}$ & $\%$ & $\begin{array}{c}\text { Area } \\
\text { (ha) }\end{array}$ & $\%$ & $\begin{array}{c}\text { Area } \\
\text { (ha) }\end{array}$ & $\%$ \\
\hline Infrastructure & 5048 & 81.7 & 210.5 & 3.4 & 0.0 & 0.0 & 235 & 3.8 & 543 & 8.8 & 142.3 & 2.3 \\
\hline Areas of use & 0.0 & 0.0 & 0.0 & 0.0 & 1.9 & 0.0 & 3082 & 49.9 & 2934 & 47.5 & 160.9 & 2.6 \\
\hline Declivity & 0.0 & 0.0 & 4480 & 72.5 & 1353 & 21.9 & 266 & 4.3 & 61.7 & 1.0 & 18.1 & 0.3 \\
\hline Altimetry & 0.0 & 0.0 & 0.0 & 0.0 & 0.0 & 0.0 & 1563 & 25.3 & 4618.8 & 74.7 & 0.0 & 0.0 \\
\hline Orientation & 0.0 & 0.0 & 2743 & 44.4 & 544 & 8.8 & 556 & 9.0 & 1742 & 28.2 & 593 & 9.6 \\
\hline $\begin{array}{l}\text { Coverage and } \\
\text { land use }\end{array}$ & 259.9 & 4.2 & 80.5 & 1.3 & 0.0 & 0.0 & 2045 & 33.1 & 1841.4 & 29.8 & 1952 & 31.6 \\
\hline
\end{tabular}

Slope and slope orientation factors were highlighted due to their representativeness in the low danger, 72.5 and $44.4 \%$, respectively. On the other hand, the factor Areas of use and coverage and land use stood out for the representativeness of the very high and extreme classes, with 50.1 and $61.4 \%$, respectively. Regarding infrastructure and their respective interference radii, $81.7 \%$ of the area presented zero risk, that is, $18.3 \%$ of the study area is under human influence, of which approximately $48 \%$ fell into the risk class very high. The altimetry covered two classes of danger, with the very high class being the most representative $(74.7 \%)$.

\section{Forest fire risk zoning}

Figure 2 represents the risk zoning of forest fires for the periods of low (A) and high (B) occurrence of fires and burned areas for the period from 2015 to 2018

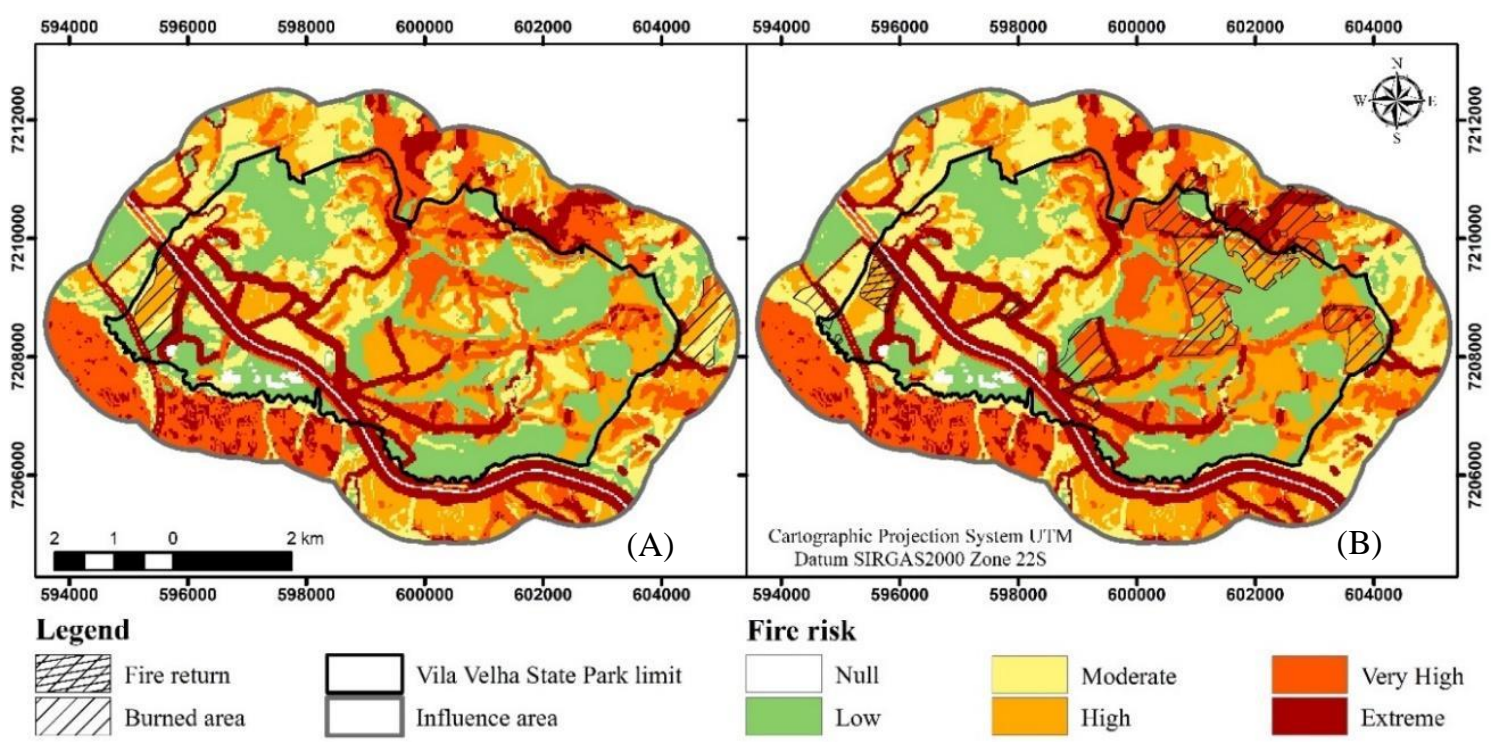

Figure 2. Forest fire risk mapping and burned area (2015 - 2018) to the Vila Velha State Park and its surroundings for: (A) the lower fire occurrence season; (B) the higher fire occurrence season

Figura 2. Zoneamento de risco de incêndios florestais e área queimada (2015 - 2018), para o Parque Estadual de Vila Velha e seu entorno, para: (A) período de baixa incidência de incêndios florestais; (B) período de alta incidência de incêndios florestais 
It was observed for both periods that the high and very high risk classes were concentrated to the east of Vila Velha State Park, while the moderate and extreme classes were concentrated to the west. Table 6 shows the representativeness of each class of forest fire risk for the two scenarios, both for the area inside the park, as well as the area surrounding the park.

Table 6. Representativeness of the forest fire risk classes for the two scenarios Tabela 6. Representatividade das classes de risco de incêndio florestal para os dois cenários

\begin{tabular}{|c|c|c|c|c|c|c|c|c|c|c|c|c|}
\hline \multirow{4}{*}{$\begin{array}{l}\text { Fire risk } \\
\text { classes }\end{array}$} & \multicolumn{12}{|c|}{ Forest fire incidence period } \\
\hline & \multicolumn{6}{|c|}{ Low incidence } & \multicolumn{6}{|c|}{ High incidence } \\
\hline & \multicolumn{2}{|c|}{ Park } & \multicolumn{2}{|c|}{ Surroundings } & \multicolumn{2}{|c|}{ Total } & \multicolumn{2}{|c|}{ Park } & \multicolumn{2}{|c|}{ Surroundings } & \multicolumn{2}{|c|}{ Total } \\
\hline & $\begin{array}{c}\text { Area } \\
\text { (ha) }\end{array}$ & $\%$ & $\begin{array}{c}\text { Area } \\
\text { (ha) }\end{array}$ & $\%$ & $\begin{array}{c}\text { Area } \\
\text { (ha) }\end{array}$ & $\%$ & $\begin{array}{c}\text { Area } \\
\text { (ha) }\end{array}$ & $\%$ & $\begin{array}{c}\text { Area } \\
\text { (ha) }\end{array}$ & $\%$ & $\begin{array}{c}\text { Area } \\
\text { (ha) }\end{array}$ & $\%$ \\
\hline Null & 41.4 & 1.3 & 28.5 & 0.9 & 69.9 & 1.1 & 41.4 & 1.3 & 28.5 & 0.9 & 69.9 & 1.1 \\
\hline Low & 1026.8 & 31.4 & 284.4 & 9.8 & 1311.2 & 21.2 & 966.8 & 29.6 & 139.2 & 4.8 & 1106.0 & 17.9 \\
\hline Moderate & 532.5 & 16.3 & 674.0 & 23.2 & 1206.5 & 19.5 & 457.4 & 14.0 & 820.4 & 28.2 & 1277.8 & 20.7 \\
\hline High & 689.3 & 21.0 & 611.8 & 21.0 & 1301.1 & 21.1 & 725.4 & 22.2 & 611.2 & 21 & 1336.6 & 21.6 \\
\hline Very High & 463.4 & 14.2 & 762.1 & 26.2 & 1225.5 & 19.9 & 570.8 & 17.4 & 773.0 & 26.6 & 1343.8 & 21.8 \\
\hline Extreme & 515.7 & 15.8 & 548.9 & 18.9 & 1064.6 & 17.2 & 507.3 & 15.5 & 537.4 & 18.5 & 1044.7 & 16.9 \\
\hline Total & 3269.1 & 100 & 2909.7 & 100 & 6178.8 & 100 & 3269.1 & 100 & 2909.7 & 100 & 6178.8 & 100 \\
\hline
\end{tabular}

For both scenarios, the null risk class represented $1.1 \%$ of the study area, referring to the road, lagoons and furnas, while the extreme risk class was concentrated in the areas of influence of the road network.

Considering the area of the park for both periods, the low risk class stood out, which had approximately $30 \%$ representativeness. This class covered areas of restricted access in which the vegetation had higher moisture content, such as the mixed montane rain forest, mixed alluvial rain forest, pioneer formation of fluvial influence, hygrophile steppe, in addition to areas with rock formations. However, considering the total study area, this risk class had an area reduction of $15.7 \%$ for the discharge period incidence of forest fires. Approximately $15.5 \%$ of the areas that previously presented low risk, presenting moderate risk.

The very high risk class covered approximately $26 \%$ of the area surrounding the park for the two periods, which included areas of agricultural crops and areas of countryside vegetation. The very high risk class had greater representativeness in the period of high fire incidence for the study area, $21.8 \%$, an increase of $9.7 \%$ in relation to the other scenario.

For the period of low incidence of forest fires, $51 \%$ of the area of Vila Velha State Park fit into the highest fire risk classes (from high to extreme), while for the high incidence of fires, this representation rose to $55.2 \%$.

During the 4-year period, 11 polygons were found with burn scars or forest fires in the study area. In the period of low incidence of forest fires, a total of 163.7 ha, distributed among classes of low risk (5.8\%), moderate $(30.8 \%)$, high $(44.1 \%)$, very high $(6.3 \%)$ and extreme $(13 \%)$. In the period of high incidence of forest fires, 599.2 ha were distributed among the classes of low risk $(7.2 \%)$, moderate $(5.0 \%)$, high $(30.8 \%)$, very high $(35.4 \%)$ and extreme $(21.6 \%)$.

\section{DISCUSSION}

The validation of forest fire risk zoning was based on burn scars, as $81.8 \%$ of these had an area of less than 100 ha, this fact that made it impossible to use hotspots for validation, considering that Pereira et al. (2012) found a failure to detect $81 \%$ for areas burned up to 100 ha. For the period of low fire incidence, two scars were observed, which reached predominantly high and moderate risk classes (74.9\%), while for the period of high incidence of fires were demarcated in nine areas, which predominantly encompassed the classes of high, very high risk and extreme (87.8\%). The recurrent area (burned in January 2015 and August 2017) totaled 40.4 ha, sorted into moderate $(6.4 \%)$, high $(63 \%)$, very high $(1 \%)$ and extreme $(29.6 \%)$ classes, with the highway margins being the probable starting point for the 2017 fire.

The most influential factor in the risk of forest fires was the human presence, a fact corroborated by other studies, which presented a very high or extreme degree of risk in areas of influence of the road network, such as de Ferraz and Vettorazzi (1998), Koproski et al. (2011) and Tetto et al. (2012). Prudente and Rosa (2010) mention that proximity to roads and urban areas contribute to the occurrence of forest fires, the probable ones being places where the fire started, mainly for criminal causes, cigarettes, religious services and bonfires. Another important factor observed was the type of vegetation. The rural typology areas stood out in terms of both scenarios, due to the high risk of forest fires in these locations. According to Seger et al. (2018), the combustible material of grassywoody steppe is classified as dangerous, since it is composed mostly of thin and dry material. According to the

FLORESTA, Curitiba, PR, v. 50, n. 4, p. 1818 - 1826, out/dez 2020.

Kovalsyki, B. et.al.

ISSN eletrônico 1982-4688

DOI: 10.5380/rf.v50 i4. 65974 
literature, the quantities of this material, as well as its vary according to the seasons, which influences the danger of forest fires in this typology, especially in more critical periods, such as winter and early spring.

Several studies point to a period similar to the one previously mentioned as the season with the highest occurrence of forest fires for different regions of Brazil. In general, spring and winter are seen as critical periods in the country, with emphasis to the months of August, September and October (CAÚLA et al., 2015). However, the behavior of forest fires is specific to each region, as the possibility of fires, as well as their frequency, is strongly related to atmospheric conditions (SOARES et al., 2017).

The inclusion of meteorological data in the risk zoning allows for spatio-temporal analysis, which enables a more concise assessment on forest fire hazard, critical scenarios and forecasts (HO et al., 2017), as well as monitoring and planning with greater safety and effectiveness. Sometimes, fire risk zonings are prepared without distinguishing critical periods of fire occurrences, however, Ho et al. (2017) cited that the danger estimated by the Monte Alegre Formula was a determining factor in the zoning that they developed for the state of Santa Catarina.

A relevant concern regarding the increased risk of fires is climate change (CAÚLA et al., 2015). Based on studies, Batista et al. (2014) predict that by the end of the century the climate will be drier in the state of Paraná, on which in its turn, interferes with moisture content and, consequently, with the flammability of combustible materials. Thus, the importance of understanding the ecological role of fire is emphasized, as well as how its regime can change and which are the post-firing responses. This allows to define effective strategies for conservation and maintenance of existing models in each ecosystem, mainly in conservation areas that encompass more than one fire response category (MYERS, 2006).

In view of the environmental changes that may occur over time, it is recommended that risk zones are updated periodically, as well as the scale of values adopted for each variable, by recording the occurrence of fires in the area of interest (KOPROSKI et al., 2011). In addition, in recent years the use of laser scans to map vegetation structure and quantify combustible material has been the subject of several studies, this enables the improvement of simulation models of fire behavior in order to assess landscape-level fire risk using spatially continuous information for forest management purposes (GONZÁLEZ-OLABARRIA et al., 2012).

\section{ACKNOWLEDGMENTS}

This study was financed in part by the Coordenação de Aperfeiçoamento de Pessoal de Nível Superior Brasil (CAPES) - Finance Code 001

\section{CONCLUSIONS}

- The risk and danger hazard variables identified for the Vila Velha State Park were sufficient for the spatial representation of the probability of occurrence of forest fires in the conservation unit;

- The period of high fire incidence extended from April to September and the predominant risk class was "Very high", with $21.8 \%$ of the study area (1343.8 ha);

- The low fire incident period was from October to March and had 31.4\% of the area of the Vila Velha State Park (1026.8 ha) classified as "low" risk;

- The priority areas for preventive actions over the two periods were the eastern portion of the park and the areas of influence of the highway.

\section{REFERENCES}

BATISTA, A. C.; OLIVEIRA, D. S.; SOARES, R. V. Zoneamento de risco de incêndios florestais para o estado do Paraná. Curitiba: FUPEF, 2002. 86 p. (Série técnica n. 2).

BATISTA, A. C.; TETTO, A. F.; DEPPE, F.; GRODZKI L.; GRASSI, J. T. Análise dos impactos das mudanças climáticas sobre o risco de incêndios florestais no estado do Paraná. Scientia Forestalis, Piracicaba, v. 42, n. 104, p. $491-501,2014$.

BOWMAN, D. M. J.; BALCH, J. K.; ARTAXO, P.; BOND, W. J.; COCHRANE, M. A.; D'ANTONIO, C. M.; DEFRIES, R. S.; JOHNSTON, F. H.; KEELEY, J. E.; KRAWCHUK, M. A.; KULL, C. A.; MACK, M.; MORITZ, M. A.; PYNE, S. J.; ROOS, C. I.; SCOTT, A. C.; SODHI, N. S.; SWETNAM, T. W. The human dimension of fire regimes on Earth. Journal of Biogeography, v. 38, n. 12, p. 2223 - 2239, 2011.

BOVIO, G.; MARCHETTI, M.; TORNARELLI, L.; SALIS, M.; VACCHIANO, G.; LOVREGLIO, R.; ELIA, M.; FIORUCCI, P.; ASCOLI, D. Gli incendi boschivi stanno cambiamo le strategie per governarli. Forest@, v. 14, p. $202-205,2017$. 
CAÚlA, R. H.; OLIVEIRA-JÚNIOR, J. F.; LYRA, G. B.; DELGADO, R. C.; HEILBRON FILHO, P. F. L. Overview of fire foci causes and locations in Brazil based on meteorological satellite data from 1998 to 2011. Environmental Earth Sciences, v. 74, n. 2, p. 1497 - 1508, 2015.

DALAZOANA, K.; MORO, R. S. Riqueza específica em áreas de campo nativo impactadas por visitação turística e pastejo no Parque Nacional dos Campos Gerais, PR. Floresta, Curitiba, v. 14, n. 2, p. 387 - 396, 2011.

FERRAZ, S. F. B.; VETTORAZZI, C. A. Mapeamento de risco de incêndios florestais por meio de sistema de informações geográficas (SIG). Scientia Forestalis, Piracicaba, v. 53, p. 39 - 48, jun. 1998.

GONZÁlEZ-OLABARRIA, J. R.; RODRÍGUEZ, F.; FERNÁNDEZ-LANDA, A.; MOLA-YUDEGO, B. Mapping fire risk in the model forest of urbión (Spain) based on airborne LiDAR measurements. Forest Ecology and Management, v. 282, p. $149-156,2012$.

HO, T. L.; BATISTA, A. C.; TETTO, A. F. Forest fire risk forecast for the state of Santa Catarina due to climate changes. Floresta, Curitiba, v. 47, n. 4, p. 427 - 436, 2017.

InSTITUTO AMBIENTAL DO PARANÁ (IAP). Plano de manejo do Parque Estadual de Vila Velha. Curitiba, 2004.

IAP Notícias: IAP participa de curso de atualização sobre manejo com fogo em unidades de conservação. Curitiba: IAP, 2018. Disponível em: < http://www.iap.pr.gov.br/2018/04/1391/IAP-participa-de-curso-deatualizacao-sobre-manejo-com-fogo-em-Unidades-de-Conservacao.html>. Acesso em: 18/06/2019.

INSTITUTO NACIONAL DE PESQUISAS ESPACIAIS (INPE). Topodata: banco de dados geomorfométricos do Brasil. São José dos Campos: INPE, 2011.

KOVAlSYKI, B. Ajuste da Fórmula de Monte Alegre (FMA) para o município de Ponta Grossa (PR). Curitiba: UFPR, 2016. (Relatório técnico).

KOPROSKI, L. P.; FERREIRA, M. P.; GOLDAMMER, J. G. BATISTA, A. C. Modelo de zoneamento de risco de incêndios para unidades de conservação brasileiras: o caso do Parque Estadual do Cerrado (PR). Floresta, Curitiba, v. 41, n. 3, p. $551-562,2011$.

MINISTÉRIO DO MEIO AMBIENTE (MMA). Catálogo de imagens de satélite RapidEye. Brasília: MMA, 2013.

MYERS, R. L. Convivendo com o fogo: manutenção dos ecossistemas e subsistência com o manejo integrado do fogo. USA: TNC, 2006. 28 p.

NITSCHE, P. R.; CARAMORI, P. H.; RICCE, W. S. da; PINTO, L. F. D. Atlas climático do estado do Paraná. Londrina: IAPAR, 2019.

PEREIRA, A. A.; PEREIRA, J. A. A.; MORELli, F.; BARROS, D. A.; ACERBI JUNIOR, F. W.; SCOLFORO, J. R. S. Validação de focos de calor utilizados no monitoramento orbital de queimadas por meio de imagens TM. Cerne, Lavras, v. 18, n. 2, p. 335 - 343, 2012.

PRUDENTE, T. D.; ROSA, R. Detecção de incêndios florestais no Parque Nacional da Chapada dos Veadeiros e área de entorno. Caminhos de geografia, Uberlândia, v. 11, n. 35, p. 209 - 221, 2010.

SEGER, C. D.; BATISTA, A. C.; TETTO, A. F.; SOARES, R. V.; BIONDI, D. Caracterização do material combustível fino da estepe gramíneo-lenhosa no estado do Paraná, Brasil. Ciência Florestal, Santa Maria, v. 28, n. 2, p. $863-874,2018$.

SISTEMA METEOROLÓGICO DO PARANÁ (SIMEPAR). Dados meteorológicos de Ponta Grossa: 2006 a 2014. Curitiba: SIMEPAR, 2015. (Banco de dados).

SOARES NETO, G. B.; BAYMA, A. P.; FARIA, K. M. S. de.; OLIVEIRA, E. G. de.; MENEZES, P. H. B. J. Riscos de incêndios florestais no Parque Nacional de Brasília - Brasil. Territorium, Portugal, v. 23, p. 161 - 170 , 2016.

SOARES, R. V.; BATISTA, A. C.; TETTO, A. F. Incêndios florestais: controle, efeitos e uso do fogo. Curitiba, 2017, 264 p.

SYSBM - CCB. Registro de ocorrência de incêndios para Ponta Grossa: 2006 a 2014. Cascavel: Corpo de Bombeiros de Cascavel, 2015.

TETTO, A. F.; BATISTA, A. C.; SOARES, R. V. Zoneamento de risco de incêndios florestais para a Floresta Nacional de Irati, estado do Paraná, Brasil. Scientia Forestalis, Piracicaba, v. 40, n. 94, p. 259 - 265, 2012. 